\title{
Chronic Lymphocytic Leukemia Presenting as a Pituitary Mass Lesion
}

\author{
Jonathan S. Fain, Faramarz Naeim, Donald P. Becker, Andre Van Herle, Frisca Yan-Go, \\ Leonard Petrus and Harry V. Vinters
}

\begin{abstract}
We describe a unique case of chronic lymphocytic leukemia (CLL) in a patient who presented with bitemporal hemianopsia, adrenal insufficiency, and gonadotrophin deficiency. Studies revealed an enhancing intrasellar mass with suprasellar extension and displacement of the optic chiasm. Peripheral blood and cerebrospinal fluid (CSF) studies disclosed a monoclonal IgM kappa expressing B-cell CLL. Biopsy of the pituitary mass revealed dense infiltration of the pituitary gland by leukemic cells. This is, to our knowledge, the first reported case of CLL presenting as a pituitary mass lesion.
\end{abstract}

RÉSUMÉ: Masse hypophysaire comme manifestation initiale d'une leucémie Iymphoïde chronique. Nous décrivons un cas unique de leucémie lymphoïde chronique (LLC) chez un patient qui s'est présenté avec une hémianopsie bitemporale, une insuffisance surrénalienne et un déficit en gonadotrophines. L'investigation a montré une masse intrasellaire avec extension suprasellaire et déplacement du chiasma optique. L'étude du sang périphérique et du liquide céphalo-rachidien a révélé la présence d'une LLC à cellules B exprimant une IgM monoclonale kappa. Une biopsie de la masse hypophysaire a révélé une infiltration dense de la glande pituitaire par les cellules leucémiques. À notre connaissance, c'est le premier cas rappotré de LLC ayant comme mode de présentation une masse pituitaire.

Can. J. Neurol. Sci. 1992; 19:239-242

Involvement of any portion of the central nervous system by chronic lymphocytic leukemia (CLL) is an exceedingly rare complication. ${ }^{1-8}$ We report a case of CLL in a patient who presented with a pituitary mass lesion which represented massive infiltration of the gland by leukemic lymphocytes.

\section{Case RePort}

A 57-year-old Asian woman was referred in February, 1991 for evaluation and treatment of a pituitary mass. She had complained the previous month of malaise, anorexia, dry cough, arthralgias, myalgias and a twelve pound weight loss developing over three weeks. She had noted diminished visual acuity in her left eye with blurring of words while reading. Past medical history was remarkable for a 15 year history of hypertension and a history of narcolepsy, currently being treated with Enalapril maleate, hydrochlorothiazide and chlorthalidone. She admitted to a 20 pack-year history of cigarette smoking (discontinued 15 years previously), and rare consumption of alcohol.

Physical examination disclosed an obese woman with blood pressure $128 / 92 \mathrm{~mm} \mathrm{Hg}$ supine, $102 / 70 \mathrm{~mm} \mathrm{Hg}$ standing, temperature $97.5^{\circ} \mathrm{F}$, a regular pulse rate of $80 / \mathrm{min}$, and respirations of 14 per minute. There was hepatosplenomegaly. Neurological examination was remarkable for a left superior temporal visual field deficit and diminished vibratory sensation in the feet bilaterally. Initial laboratory studies included: serum sodium $120 \mathrm{mEq} / \mathrm{l}$; serum glucose $130 \mathrm{mg} / \mathrm{dl}$; lactate dehydrogenase $222 \mathrm{U} / \mathrm{L}$; serum levels of potassium, blood urea nitrogen, creati- nine, uric acid, aspartate amino transferase, alanine amino transferase, total and direct bilirubin were normal. Complete blood count with differential: WBC $15.6 \times 10^{3} / \mathrm{cu} \mathrm{mm}$ with $6 \%$ segmented neutrophils, $74 \%$ lymphocytes, $2 \%$ basophils and $18 \%$ monocytes; RBC $4.70 \times 10 \% \mathrm{cu}$ $\mathrm{mm}$, hemoglobin $13.9 \mathrm{~g} / \mathrm{dl}$, hematocrit 39.9 , platelets $122 \times 10^{3} / \mathrm{cu} \mathrm{mm}$. Total serum T4 was $3.0 \mathrm{ug} / \mathrm{dl}$ (normal, $3.2-7.2 \mathrm{ug} / \mathrm{dl}$ ), thyroid-stimulating hormone (TSH) $0.5 \mathrm{uU} / \mathrm{ml}$ (normal, $0.5-4.8 \mathrm{uU} / \mathrm{ml}$ ), serum prolactin $58 \mathrm{ng} / \mathrm{ml}$ (normal, 3-24 ng/ml), follicle-stimulating hormone (FSH) $3.0 \mathrm{mIU} / \mathrm{ml}$ (normal range in postmenopausal state, $20-160 \mathrm{mIU} / \mathrm{ml}$ ), luteinizing hormone (LH) $1.9 \mathrm{mIU} / \mathrm{ml}$ (normal postmenopausal, 25$70 \mathrm{mlU} / \mathrm{ml}$ ), estradiol $0.5 \mathrm{ng} / \mathrm{dl}$ (normal postmenopausal, less than $1.5 \mathrm{ng} / \mathrm{dl}$ ), growth hormone $(\mathrm{GH}) 1.4 \mathrm{ng} / \mathrm{ml}$ (normal, $0.7-6.0 \mathrm{ng} / \mathrm{ml}$ ), 8 AM serum cortisol $1.4 \mathrm{ug} / \mathrm{dl}$ (normal, $8-19 \mathrm{ug} / \mathrm{dl}$ ). Results of an overnight metapyrone test were: 11-desoxycortisol (compound $S$ ) less than $1.0 \mathrm{ug} / \mathrm{dl}$ (normal, $7-18 \mathrm{ug} / \mathrm{dl}$ ). The Westergren sedimentation rate was $40 \mathrm{~mm} / \mathrm{hr}$.

A computerized axial tomographic (CT) scan of the brain revealed a homogeneously enhancing mass located in the region of the sella turcica (Figure 1). Magnetic resonance imaging (MRI) of the pituitary gland with gadolinium showed a $7 \times 16 \mathrm{~mm}$ homogeneous, enhancing pituitary mass with suprasellar extension and superior displacement of the optic chiasm (Figures 2a-c). There was no extension of the mass lateral to the carotid vessels and no invasion of the floor of the sella. Formal visual field studies demonstrated superior bitemporal hemianopsia consistent with optic chiasm compression by the pituitary mass.

A liver-spleen scan with $99 \mathrm{~m}$ Technetium sulfur colloid showed splenomegaly with increased splenic uptake and an abdominal CT scan

From the Departments of Pathology and Laboratory Medicine (J.S.F., F.N., H.V.V.), Surgery (Neurosurgery) (D.P.B.), Medicine (A.V.H.), Neurology (F.Y.-G.), and Radiological Sciences (L.P.), UCLA Medical Center, Los Angeles, California

Received August 13, 1991. Accepted in final form December 1991

Reprint requests to: Harry V. Vinters, M.D., Division of Neuropathology, Department of Pathology and Laboratory Medicine, UCLA Medical Center, CHS 18-170, Los Angeles, California, U.S.A. 90024-1732 


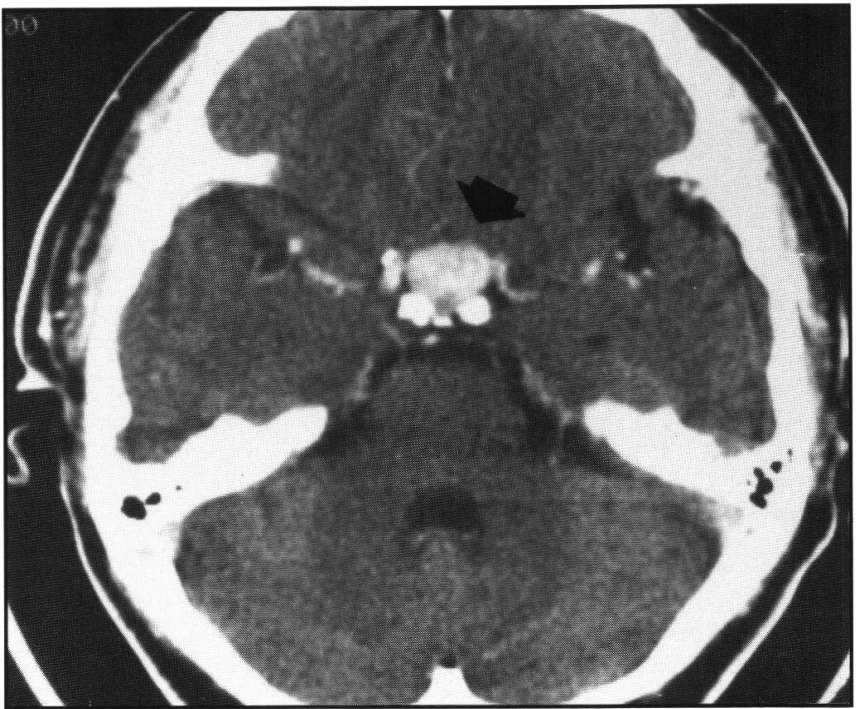

Figure I - Axial post-contrast CT scan shows a homogeneously enhancing mass (arrow) located in the region of the sella turcica.

confirmed splenomegaly without evidence of lymphadenopathy. Bone marrow evaluation demonstrated a cellular, erythroid predominant marrow with a modest diffuse, interstitial increase of small mature appearing lymphocytes representing approximately $28 \%$ of the hematopoietic cell population.

The patient's serum sodium returned to normal levels with administration of fluids and $\mathrm{NaCl}$ tablets. She was started on Prednisone and Synthroid replacement therapy and referred for neurosurgical evaluation and treatment in February, 1991.

A transnasal-transsphenoidal resection of the pituitary mass was performed. Gross total removal was obtained.

Microscopic examination of the resected specimen showed pituitary tissue extensively effaced by sheets of monomorphous lymphocytes with few remaining residual islands of anterior pituitary cells (Figures $3 \mathrm{a}$ and $3 \mathrm{~b}$ ). The lymphocytes were small with dark nuclei, clumped nuclear chromatin, occasional single prominent nucleoli and scant cytoplasm. No plasmacytoid differentiation of plasma cells was seen. There were no mitotic figures or necrosis. There was scattered hemosiderin, indicative of old hemorrhage. Immunoperoxidase studies with monoclonal antibodies on formalin fixed, paraffin-embedded material showed the lymphocyte infiltrate to be diffusely positive for LCA (CD45) (leukocyte common antigen, DAKO, Carpinteria, CA; 1:200) (Figure 3c). The majority of these cells also showed weak to moderate cytoplasmic positivity for $\mathrm{L} 26$ (CD20) (DAKO; 1:400), a monoclonal antibody directed against $\mathrm{B}$ cells and scattered lymphocytes showed strong membranous staining for UCHLI (CD45RO) (DAKO; 1:50), a monoclonal antibody directed against $\mathrm{T}$ cells. Residual anterior pituitary cells showed patchy strong cytoplasmic positivity for growth hormone and scattered strong positivity for chromogranin.

The patient was well post-operatively without significant complications, and remained neurologically intact. A subsequent serum immunoelectrophoresis demonstrated a monoclonal IgM Kappa gammopathy. Examination of a peripheral blood smear revealed a dimorphic lymphocyte population. Approximately $65 \%$ of the cells were small lymphocytes with regular nuclear outlines, clumped chromatin, high nuclear to cytoplasmic ratio with scanty cytoplasm, and absent nucleoli. The remaining $35 \%$ of the lymphocytes were larger with a lower nucleus to cytoplasmic ratio and a single prominent nucleolus, an appearance consistent with prolymphocytes. Flow cytometry of a gated lymphocytepredominant population from lysed whole blood showed: CD3 $11 \%$, CD4 6\%, CD5 15\%, CD8 8\%, CD19 85\%, CD20 86\%, CD24 82\%, Kappa $80 \%$, Lambda $1 \%$, IgG $1 \%$, IgM $20 \%$. The peripheral blood cytology and flow cytometry phenotype were consistent with an IgM
Kappa, B-cell chronic lymphocytic leukemia, mixed cell type (chronic lymphocytic leukemia/prolymphocytic leukemia), which includes cases with more than $10 \%$ and less than $55 \%$ prolymphocytes. ${ }^{9} \mathrm{~A}$ subsequent lumbar puncture showed cerebrospinal fluid (CSF) containing $70 \mathrm{mg} / \mathrm{dl}$ of glucose and $22 \mathrm{mg} / \mathrm{dl}$ of protein. Bacteriologic studies were negative. The CSF leukocyte count was $12 \times 10^{6} / \mathrm{L}$ with $95 \%$ lymphocytes and $5 \%$ monocytes and the CSF erythrocyte count was $2 \times 10^{6} / \mathrm{L}$. Immunoperoxidase staining of the CSF cytocentrifuge preparation demonstrated the lymphocytes to be of IgM monoclonal kappa phenotype.

\section{Discussion}

Involvement of the central nervous system by chronic lymphocytic leukemia (CLL) is a rare complication. ${ }^{1-8}$ Most of these patients have presented with leukemic meningitis. ${ }^{2-8}$ Only one previous report describes CLL presenting as a mass lesion in the brain, which involved the hypothalamus and obstructed the foramen of Munro.' Examination of ventricular fluid demonstrated leukemic cells with monoclonal lambda B phenotype.

CLL presenting with clinical manifestations as a mass lesion in the pituitary, has, to our knowledge not been previously reported. CLL pituitary infiltrates have been found incidentally in $20 \%$ of CLL cases in a large autopsy series. ${ }^{10} \mathrm{CT}$ and MRI scans in our patient showed an enhancing pituitary mass with compression of the optic chiasm, indistinguishable from a pituitary adenoma.

The initial differential diagnosis of resected pituitary tissue included lymphocytic hypophysitis. This is a rare cause of pituitary enlargement and hypopituitarism, thought to be autoimmune in nature. ${ }^{11}$ Since the initial report by Goudie and Pinkerton, ${ }^{12}$ over 30 cases have been reported in the literature on the basis of histological findings, the vast majority of affected patients having been women in the early postpartum period. ${ }^{13}$ Histologically, lymphocytic hypophysitis shows infiltration of the anterior pituitary gland with small lymphocytes occasionally arranged in follicles with germinal centers, the presence of scattered plasma cells and histiocytes, and often evidence of fibrosis. ${ }^{11.14}$ Two recent studies have immunophenotyped the lymphocyte population. ${ }^{14,15}$ One group found a mixture of $\mathrm{T}$ and $\mathrm{B}$ cells, the $B$ cells being present in well defined lymphoid follicles. ${ }^{14}$ The other study showed a predominance of $T$ cells with few, scattered B cells. ${ }^{15}$ Both reports demonstrated a CD4:CD8 (T helper-inducer:T cytoxic-suppressor) ratio of 2:1.

Our case, although superficially resembling lymphocytic hypophysitis, differs in that the lymphocytic infiltration was diffuse, massive, monomorphous, and monotypic without the presence of plasma cells, histiocytes or germinal centers. In addition, the lymphocytes were morphologically identical to the leukemic lymphocyte population observed in the peripheral blood and CSF.

In our patient, this pituitary leukemic infiltrate caused symptoms and signs similar to those seen in pituitary adenomas: compression of the optic chiasm resulting in visual field deficits, and endocrine deficiencies including secondary adrenal insufficiency and gonadotrophin deficiency. The relatively rapid evolution of the patient's clinical picture might, in retrospect, have suggested a neoplastic disease other than pituitary adenoma, which might be expected to produce a more slowly progressive deficit, e.g. visual field abnormalities. In terms of the patient's endocrine abnormalities, her hyponatremia may have reflected inappropriate secretion of antidiuretic hormone $(\mathrm{ADH})$, possibly related to 
an insufficiency of cortisol and/or thyroxine. The other endocrine deficiencies observed, e.g. adrenal, gonadotropin and thyroid deficiencies, were almost certainly secondary to anterior pituitary involvement by leukemic cells.

CT and MRI scans showed an enhancing pituitary mass. A leukemic infiltrate of the pituitary gland should therefore be considered in the differential diagnosis of patients presenting with CLL and a pituitary mass. Indeed, rapid evolution of signs and symptoms referable to the region of the sella turcica should prompt clinicians to search for systemic disease involving the hypothalamic-pituitary region.
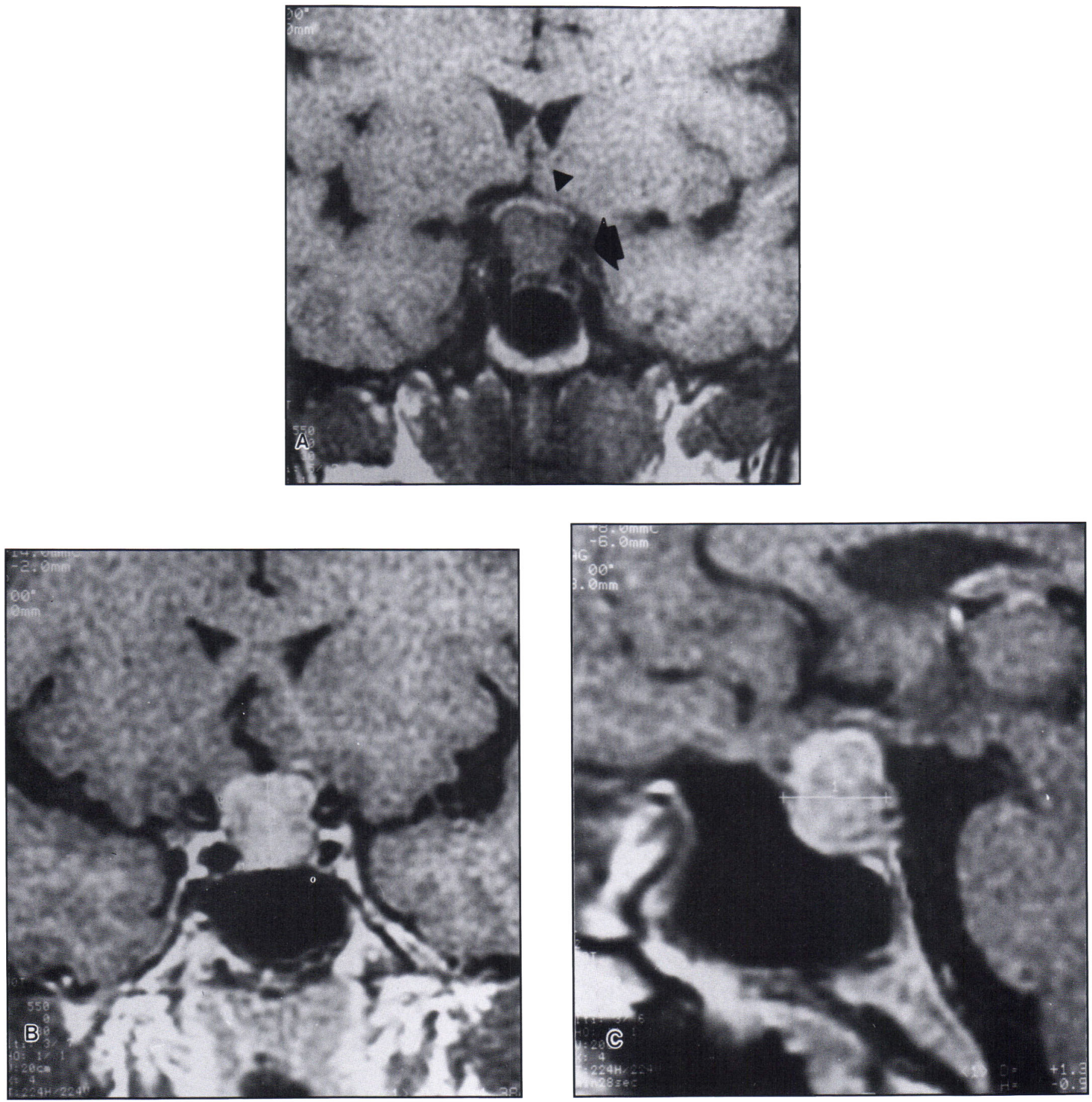

Figure 2 - A. Pre-gadolinium coronal TI MRI scan demonstrates an intrasellar mass (arrow) with suprasellar extension and displacement of the optic chiasm (arrowhead). B. and C. Post-gadolinium coronal and sagittal scans reveal uniform enhancement of the sellar mass. There is no lateral extension beyond the carotid arteries and no invasion of the floor of the sella. 

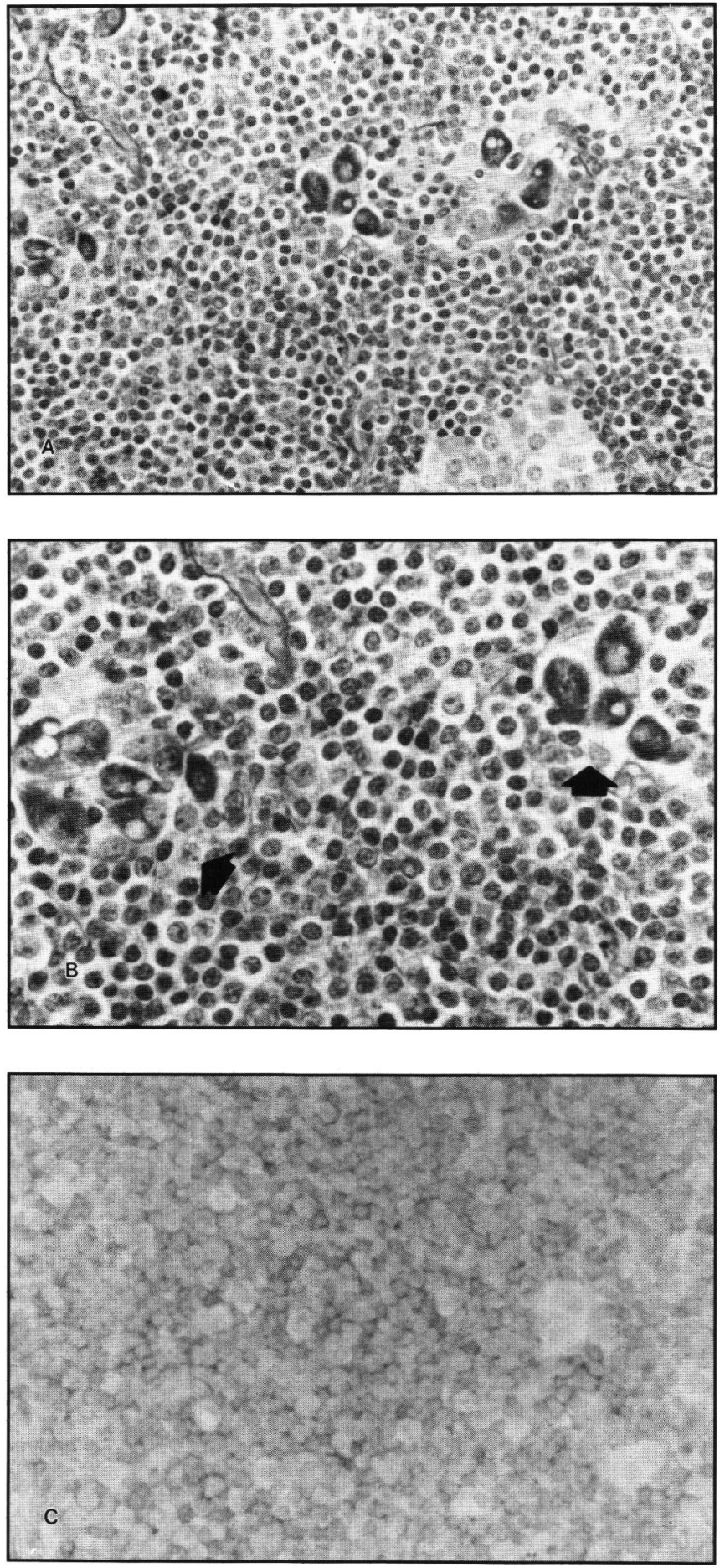

Figure 3 - A. Anterior pituitary tissue is extensively effaced by sheets of lymphocytes (PAS-orange $G, \times 250$ ). B. Monomorphous lymphocyte population with two residual islands of anterior pituitary cells (arrow's) (PAS-orange $G, \times 400$ ). C. Immunohistochemistry demonstrates diffuse positive staining of the lymphocyte population for leukocyte common antigen $(\times 400)$.

\section{REFERENCES}

1. Garofalo M Jr, Murali RAJ, Halperin I, et al. Chronic lymphocytic leukemia with hypothalamic invasion. Cancer 1989; 64: 17141716.

2. Gétaz EP, Miller GJ. Spinal cord involvement in chronic lymphocytic leukemia. Cancer 1979; 43: 1858-1861.

3. Lane PK, Townsend RM, Beckstead JH, et al. Central nervous system involvement in a patient with chronic lymphocytic leukemia and non-Hodgkin's lymphoma (Richter's syndrome), with concordant cell surface immunoglobulin isotypic and isophenotypic markers. Am J Clin Pathol 1988; 89: 254-259.

4. Liepman MK, Votaw ML. Meningeal leukemia complicating chronic lymphocytic leukemia. Cancer 1981; 47: 2482-2484.

5. López Guillermo A, Cervantes F, Bladé J, et al. Central nervous system involvement demonstrated by immunological study in prolymphocytic variant of chronic lymphocytic leukemia. Acta Haemat 1989; 81: 109-111.

6. Oshimi K, Akahoshi M, Hagiwara N, et al. A case of T-cell chronic lymphocytic leukemia with an unusual phenotype and central nervous system involvement. Cancer 1985; 55: 1937-1942.

7. Stagg MP, Gumbart $\mathrm{CH}$. Chronic lymphocytic leukemic meningitis as a cause of the syndrome of inappropriate secretion of antidiuretic hormone. Cancer 1987; 60: 191-192.

8. Steinberg JP, Pecora M, Lokey JL. Leukemic meningitis in B-cell chronic lymphocytic leukemia. Cancer Treat Rep 1985; 69: 687688.

9. Bennett JM, Catovsky D, Daniel M-T, et al. Proposals for the classification of chronic (mature) B and $\mathrm{T}$ lymphoid leukaemias. J Clin Pathol 1989; 42: 567-584.

10. Barcos M, Lane W, Gomez GA, et al. An autopsy study of 1206 acute and chronic leukemias (1958 to 1982). Cancer 1987; 60 : 827-837.

11. Asa SL, Bilbao JM, Kovacs K, et al. Lymphocytic hypophysitis of pregnancy resulting in hypopituitarism: a distinct clinicopathologic entity. Ann Intern Med 1981; 95: 166-171.

12. Goudie RB, Pinkerton PH. Anterior hypophysitis and Hashimoto's disease in a young woman. J Pathol Bacteriol 1962; 83: 584-585.

13. Hayashi H, Yamada K, Kuroki T, et al. Lymphocytic hyphophysitis and pulmonary sarcoidosis. Report of a case. Am J Clin Pathol 1991; 95: 506-511.

14. Jensen MD, Handwerger BS, Scheithauer BW, et al. Lymphocytic hypophysitis with isolated corticotropin deficiency. Ann Intern Med 1986; 105: 200-203.

15. McCutcheon IE, Oldfield EH. Lymphocytic adenohypophysitis presenting as infertility. Case report. J Neurosurg 1991; 74: 821-826. 